\title{
MODEL CONTEXTUAL TEACHING AND LEARNING BERBASIS TRI KAYA PARISUDHA TERHADAP KOMPETENSI PENGETAHUAN IPA SISWA KELAS V
}

\author{
Anak Agung Istri Mira Utari Dewi ${ }^{1}$, Ida Bagus Surya Manuaba ${ }^{2}$, M.G Rini Kristiantari ${ }^{3}$ \\ 123Jurusan Pendidikan Dasar, Universitas Pendidikan Ganesha, Singaraja, Indonesia \\ E-mail: agungmira22@gmail.com
}

\begin{abstract}
Abstrak
Hal yang melatarbelakangi penelitian ini muatan materi IPA sulit dipahami, siswa tidak mau bertanya saat mengalami kesulitan belajar mengakibatkan rendahnya Kompetensi Pengetahuan IPA sehingga KKM tidak tercapai secara optimal. Tujuan penelitian ini untuk menganalisis pengaruh model Contextual Teaching and Learning Berbasis Tri Kaya Parisudha terhadap Kompetensi Pengetahuan IPA siswa kelas V SDN Gugus VIII Kecamatan Gianyar. Jenis penelitian ini yaitu Quasi Eksperimen (eksperimen semu), serta untuk mengetahui kesetaraan kelompok dalam Pretest digunakan rancangan desain Non Equivalen Control Group Design. Sebelum melakukan kesetaraan kelompok terlebih dahulu diketahui populasi yang dgunakan yaitu keseluruh siswa kelas V SD Gugus VIII Kecamatan Gianyar yang berjumlah 152 siswa. Sampel penelitian ini ditentukan dengan cara teknik random sampling. Dalam sampel penelitian ini kelompok eksperimen ialah SDN 1 Siangan yang berjumlah 38 orang siswa dan sebagai kelompok kontrol yaitu SDN 3 Siangan yang berjumlah 36 orang siswa. Metode tes yang digunakan sebagai pengumpulan data siswa yaitu tes objektif. Data yang dianalisis yaitu Kompetensi Pengetahuan IPA. Data yang diperoleh dianalisis dengan menggunakan teknik analisis uji-t dengan rumus pollend varians. Pada kelompok eksperimen rerata kompetensi pengetahuan IPA yaitu $\bar{x}=83,97$ dan kelompok kontrol $\bar{x}=76,91$. Analisis data dalam penelitian ini menunjukkan bahwa thitung $=3,922>$ tabel $=2,000$ pada taraf signifikansi $5 \%, \mathrm{dk}=38+36-2=72$, sehingga $\mathrm{H}_{0}$ ditolak dan $\mathrm{H}_{\mathrm{a}}$ diterima berarti terdapat perbedaan yang signifikan kompetensi pengetahuan IPA kelompok siswa yang dibelajarkan dengan model Contextual Teaching and Learning berbasis Tri Kaya Parisudha dengan kelompok siswa yang dibelajarkan secara konvensional pada siswa kelas V SDN gugus VIII Tahun Ajaran 2019/2020. Berdasarkan pemerolehan analisis data Kompetensi Pengetahuan IPA rerata kelompok eksperimen lebih tinggi dibandingkan kelompok kontrol sehingga penerapan model Contextual Teaching and Learning Berbasis Tri Kaya Parisudha dapat meningkatkan hasil Kompetensi Pengetahuan IPA siswa kelas V, sehingga model Contextual Teaching and Learning Berbasis Tri Kaya Parisudha berpengaruh terhadap Kompetensi Pengetahuan IPA siswa kelas V SDN Gugus VIII Tahun Ajaran 2019/2020.
\end{abstract}

Kata Kunci: CTL; Tri Kaya Parisudha; Kompetensi Pengetahuan IPA

\begin{abstract}
The background of this research is that the content of science material is difficult to understand, students do not want to ask questions when experiencing learning difficulties resulting in low science knowledge competencies so that KKM is not reached optimally. The purpose of this study was to analyze the effect of the Parisian-Rich Triextual Contextual Teaching and Learning model on the Science Knowledge Competence of fifth grade students of SDN Cluster VIII, Gianyar District. This type of research is Quasi Experiment (quasi-experimental), as well as to determine the equality of groups in the Pretest design Non Equivalent Control Group Design design. Before carrying out group equality first, it is known that the population used is the entire class V students of Elementary School VIII, Gianyar District, which amounted to 152 students. The research sample was determined by random sampling technique. In this study sample the experimental group was SDN 1 Siangan which amounted to 38 students and as a control group was SDN 3 Siangan which amounted to 36 students. The test method used as a student data collection is an objective test. The data analyzed are Science Knowledge Competence. The data obtained were analyzed using t-test analysis techniques with the pollend variance formula. In the experimental group the average level of science knowledge competence is ${ }^{-} \mathrm{x}=83.97$ and the control group ${ }^{-} \mathrm{x}=76.91$. Analysis of the data in this study showed that tcount $=3,922>$ ttable $=2,000$ at a significance level of $5 \%, d \mathrm{k}=38+36-2$ $=72$, so $\mathrm{HO}$ was rejected and $\mathrm{Ha}$ was accepted meaning there was a significant difference in the science knowledge competencies of the group of students taught by the model Contextual Teaching and Learning based on Tri Rich Parisudha with a group of students who are taught conventionally to students in class V SDN cluster VIII Academic Year 2019/2020. Based on the acquisition of data analysis the average Science Knowledge Competency of the experimental group is higher than that of the control group so that the application of the Triud Parisudha-based Contextual Teaching and Learning model can improve the results of the Science Knowledge Competency of fifth grade students, so that the Contextual Teaching and Learning Model Based on Tri
\end{abstract}


Rich Parisudha affects the Knowledge Competency Science students in class V SDN Cluster VIII Academic Year $2019 / 2020$.

Keywords: Ctl; Tri Kaya Parisudha; IPA Knowledge Competence

\section{PENDAHULUAN}

Pemerintah berupaya meningkatkan mutu pendidikan agar kedepannya pendidikan di Indonesia semakin baik. Dalam pendidikan disusunlah sebuah rencana tertulis yakni kurikulum dalam mencapai tujuan dari pendidikan. Untuk menumbuhkan mutu pendidikan salah satunya pada tingkat SD, sesungguhnya banyak cara dan usaha yang dapat ditempuh pemerintah antara lain, peningkatan pengadaan buku bacaan khususnya dalam buku pelajaran, peningkatan kualitas guru yang berguna untuk meningkatkan kualitas pada semua mata pelajaran bagi siswa disekolah, serta pembaharuan kurikulum. Oleh karena itu, pemerintah saat ini telah menerapkan kurikulum 2013. Selain itu, dalam melaksanakan rancangan pembelajaran guru sangatlah berperan aktif dalam memberikan suatu materi pembelajaran kepada siswa agar penguasaan kompetensi pengetahuan siswa dapat berjalan secara optimal. Keberadaan guru merupakan pelaku utama dalam menentukan berhasil tidaknya proses pembelajaran yang diterapkan. Berkaitan dengan tugas guru, maka dalam merencanakan suatu pembelajaran mampu menciptakan pembelajaran yang menarik dan menyenangkan. Pendapat ini sejalan dengan Yunita (2019) guru yang profesional yakni guru yang bisa mendesain pembelajaran dengan semenarik mungkin, sehingga menjadi senang mengikuti setiap proses pembelajaran. Widianingrum (2018) melalui student center guru dapat mengembangkan kretivitas siswa, sehingga siswa dapat berpikir dan mengembangkan idenya sendiri agar mencapai tujuan yang optimal.

Dalam muatan IPA yang diterapkan pada proses pembelajaran di SD diharapkan kepada siswa untuk memiliki pengetahuan, konsep, dan gagasan yang didapatkan siswa dari peristiwa sekelilingnya melalui pengalaman mereka dengan mengedepankan proses serangkaian ilmiah. Dengan demikian siswa dapat memahami pelajaran pada setiap bidang ilmu pengetahuan, salah satunya yaitu Ilmu Pengetahuan Alam (IPA). Arini, dkk (2020) menyatakan bahwa IPA adalah ilmu yang mempelajari berbagai peristiwa alam. Peneliti lainnya Kabanga, dkk (2020) menyatakan IPA adalah ilmu yang menjadi wahana bagi siswa untuk mengenal alam sekitar. Putri (2019) IPA adalah sebuah ilmu pasti yang didalamnya memuat segala sesuatu tentang alam dan perubahannya. Upaya inovatif yang diterapkan ketika membelajarkan siswa yaitu dengan menerapkan model pembelajaran, media pembelajaran yang atraktif dan menyenangkan serta tetap bersifat edukatif, sehingga suasana pembelajaran IPA dapat terwujud disekolah serta mampu membangkitkan siswa untuk belajar aktif serta mengembangkan rasa ingin tahu siswa (Yuliana, 2018). Dalam melaksanakan pembelajaran IPA di SD dilakukan secara kompleks terhadap penyelesaian suatu permasalahan dikarenakan memiliki konsep-konsep terkesan sulit dipahami. Untuk itu dalam mempermudah guru melakukan proses pembelajaran, terlebih dahulu guru memhami berbagai macam teori pembelajaran IPA di SD untuk mendukung kegiatan pembelajaran. Dari sekian teori pembelajaran terdapat satu teori pembelajaran yang mampu digunakan terhadap proses pembelajaran IPA di SD salah satunya teori belajar Bruner, teori belajar ini mengembangkan model penemuan. Model penemuan ini siswa dapat mencari secara mandiri dalam memperoleh suatu informasi dengan bantuan guru atau dengan menggunakan benda konkret (Sudjana, 2013). Proses pembelajaran IPA pemberian kompetensi kompetensinya agar memahami alam sekitar secara kritis (Warsiki, 2018). Pembelajaran IPA dapat menumbukan rasa keingintahuan siswa pada pengetahuan dan juga meningkatkan keterampilan proses serta kesadaran untuk lebih menghargai alam ciptaan Tuhan dengan cara menjaga dan melestarikan lingkungan disekitar kita. Pembelajaran IPA diajarkan "mencari tahu" serta "bertindak", oleh karena itu siswa mendapatkan pemahaman tentang apa yang dicari pada alam sekitarnya. Muatan IPA penting untuk diketahui dengan baik oleh siswa karena dalam pembelajaran IPA siswa dapat mengetahui segala yang ada di dalam diri siswa dan lingkungan sekitar, dengan demikian dapat apa yang telah dipelajari dapat berguna bagi siswa dalam menerapkannya di kehidupan sehari-hari.

Dari hasil observasi yang terlaksana pada hari selasa 12 November 2019 di SDN Gugus VIII Tahun Ajaran 2019/2020 terdapat temuan yaitu pembelajaran IPA sulit dipahami, karena kebanyakan menggunakan bahasa asing yang tidah mudah dipahami oleh siswa. Sehingga mengakibatkan kurang antusias dan kurang aktif mengikuti pelajaran pada muatan IPA serta beberapa peserta didik kurang berkonsentrasi dan minimnya antusias peserta didik sehingga menyebabkan pikiran siswa menjadi kacau, pemahaman peserta tentang materi IPA masih kurang, sedikit peserta didik yang mau 
menyampaikan pendapat, peserta didik kurang berpartisipasi dalam kegiatan kelompok praktikum maupun diskusi kelompok, peserta didik tidak mau bertanya saat mengalami kesulitan belajar, sehingga akan mempengaruhi kompetensi pengetahuan peserta didik. Kompetensi pengetahauan peserta didik yang kurang menyebabkan nilai yang didapat oleh peserta didik menjadi dibawah rerata. Akibatnya model pembelajaran yang digunakan terlalu menoton menjadikan siswa kurang berantusias, kurang bersemangat serta cepat bosan pada saat mengikuti proses belajar. Penelitian ini didukung oleh penelitian yang dilakukan oleh Aningsih (2019) permasalahan pada rendahnya pemahaman konsepl IPA siswa kelas III pada mata pelajaran IPA dilihat dari kuangnya kemampuan siswa dalam menjelaskan kembali konsep yang telah dipelajari dengan menggunakan bahasa sendiri, kurangnya kemampuan siswa dalam memberikan contoh contoh konsep misalnya ketika diminta untuk memberikan contoh dari masing-masing jenis gerak benda hanya sebagian kecil saja yang mampu menjawabnya. Menurut Herlina (2019) Hambatan dalam pembelajaran IPA diataranya siswa yang kurang tertarik pada pembelajaran IPA, karena mengalami kesulitan dan menjawab soal-soal IPA, sehingga berimbas pada hasil belajar IPA yang rendah bila dibandingkan dengan mata pelajaran lainnya. Rani (2019) rendahnya Kompetensi Penggetahuan IPA disebabkan oleh kurang aktifnya siswa dalam kegiatan pembelajran, siswa cepat merasa bosan, siswa malu serta takut dalam bertanya sehingga banyak siswa hanya menjadi pendengar dan penerima informasi, kurangnya inovasi dan imajinatif dalam menerapkan pembelajaran. Pada jenjang Sekolah Dasar muatan materi IPA memegang peran penting sebagai dasar siswa dalam mempelajari konsep-konsep IPA dan gejala gejala alam tertentu untuk dijadikan pengetahuan awal dalam mempelajari IPA dijenjang pendidikan selanjutnya (Rahmawati, 2018). Dari permasalahan tersebut bahwa mata pelajaran IPA dianggap sulit oleh siswa, sehingga menyebabkan rendahnya Kompetensi Pengetahuan IPA.

Sehingga kompetensi pengetahuan IPA menjadi fokus permasalahan, Fokus permasalahan tersebut dapat dilihat dari tingkat pencapaian kompetensi pengetahuan IPA peserta didik masih belum optimal dilihat dari nilai PTS peserta didik yang masih dibawah KKM. Hal ini terbukti dari hasil pencapaian kompetensi pengetahuan IPA diperoleh dari nilai PTS peserta didik yaitu, dari 152 peserta didik kelas V SDN Gugus VIII Kecamatan Gianyar, 87 orang siswa atau 57,23\% sudah mencapai KKM, sedangkan 65 orang siswa atau 42,76\% belum mencapai KKM. Berdasarkan hasil penelitian yang lain juga menemukan permasalahan yang sama seperti penelitian yang dilakukan oleh Laindjong (2014) menunjukkan hasil kompetensi pengetahuan IPA dari 334 siswa diperoleh 148 siswa atau sekitar 44,32\% yang belum mencapai KKM. Widiantini ( 2017) sebanyak 77 peserta didik mendapatkan nilai IPA dibawah re-rata atau 19,7\% dari 390 siswa. Arisantiani (2017) menyatakan bahwa rata-rata nilai akhir kompetensi pengetahuan IPA siswa kurang optimal yakni di bawah nilai KKM, siswa dikatakan tuntas apabila memenuhi nilai KKM sekitar 68,00. Dalam proses pembelajaran IPA dapat dinyatakan berhasil jika aspek pembelajaran yang sudah dilaksanakan dapat terlaksana dengan optimal. Dalam mecapai tujuan diperlukan komponen yang menunjang pembelajaran. Sehingga perlu mengemas pembelajaran yang inovatif dan pengembangan ide yang kreatif, seperti penggunaan model, media, serta sumber belajar yang menunjang sehingga apa yang diharapkan dalam proses belajar berjalan dengan baik. Hasil temuan tersebut juga dinyatakan pada penelitian Triyana (2020) yaitu selama proses pembelajaran berlangsung siswa masih terlihat ribut dan tidak memperhatikan saat guru mengajar di kelas. Hal tersebut dapat disebabkan oleh kurangnya variasi dan inovasi model-model pembelajaran sehingga dapat menjadikan pembelajaran masih satu arah. Kemudian, penggunaan media sangat penting karena bisa bertambahnya perhatian siswa maupun menjadikan siswa lebih berpartisipasi saat berjalannya pembelajaran. Dalam permasalahan tersebut sudah beberapa usaha dilakukan seorang guru dalam menambah perhatian siswa dan siswa dapat menguasai kompetensi pengetahuan khususnya dalam mata pelajaran IPA. Guru juga harus bisa kreatif dan lebih memanfaatkan apapun guna mendukung kegiatan pembelajaran (Ayu 2020). Salah satu cara dalam menunjang kegiatan belajar dengan lebih banyaknya inovasi model pembelajaran.

Hal ini menyebabkan mental siswa menjadi menurun dan kurang percaya diri.Yulianti dkk, (2019) cara yang digunakan agar siswa aktif dalam pembelajaran yanitu menerapkan model pembelajaran yang berpusat pada siswa. Selain bersifat aktif dan dapat menjaga etika siswa dalam bersikap. Salah satunya adalah melalui model Contextual Teaching and Learning berbasis Tri kaya Parisudha. Faizan (2020) dengan adanya model ini siswa dapat mengkontruksi pengetahuan dan pengalaman siswa dengan terlibat aktif baik secara berkelompok dan perorangan. Sedangkan peneliti lainnya Paramitha (2019) berpendapat dalam model pembelajaran ini guru sebagai fasilitator, dalam menyelesaikan permasahan dan menjelaskan konsep. Model Contextual Teaching and Learning 
merupakan model pembelajaran langsung. Model Contextual Teaching and Learning merupakan model yang menghubungkan suasana tertentu yang berkaitan dengan kegiatan disekelilingnya. Hal ini sependapat dengan Rahmawati (2018) model pembelajaran ini dimana peserta didik berperan aktif (student center), yang dapat mengajak siswa mencari pengetahuannya melewati berbagai pengalaman. Tahapan dari model ini mengarahkan siswa agar dapat menguasai sendiri konsep-konsep IPA dan membangun pengetahuannya sendiri melalui mencari informasi. Sedangkan Wati (2015) ketujuh langkah-langkah dari model Contextual Teaching and Leraning patut untuk dikedepankan, karena melaui fase tersebut mengajak siswa secara aktif mandiri mengembangkan konsep - konsep sendiri, melalui interaksi siswa yang lainnya. Yunus, dkk (2018) Dalam model ini secara individu siswa yang aktif membangun pengetahuannya, sedangkan guru lebih berperan sebagai fasilitator Penggunaan model Contextual Teaching and Learning, akan memberikan tantangan pada siswa dalam meningkatkan hasil belajarnya di kelas. Tri Kaya Parisudha merupakan tiga prilaku atau perbuatan yang disucikan. Menurut Suhardana (2007)ada tiga tingkah laku yang harus disucikan disebut Tri kaya Parisudha. Pikiran, perkataan, dan perbuatan merupakan bagian dari . Pikiran yang tidak baik, capan yang tidak baik, serta tingkahlaku yang tidak baik agar mampu dikendalikan, apabila ketiga ajaran Tri Kaya parisudha dapat dikendalikan maka akan membuahkan hasil perbuatan positif serta tidak merugikan pihak lain maupun diri sendiri. Tri Kaya Parisudha dapat diterapkan saat kegiatan seharihari, seperti pada dunia pendidikan dapat membentuk individu yang berkarakter baik. Sehingga penerapan Tri Kaya Parisudha bertujuan agar siswa mampu berpikir kritis, terampil dan berani berbicara dalam mencari atau memperoleh pengetahuan (Suanthara, 2018). Pengetahuan itu akan lebih bermakna manakala ditemukan dan dibangun sendiri oleh siswa untuk menerapkan pengetahuan dan keterampilan akdemik mereka dalam berbagai macam tatanan kehidupan baik di sekolah maupun diluar sekolah (Ruiyanti, 2015).

Penerapan model pembelajaran Contextual Teaching and Learning di dukung oleh hasil penelitian yang sebelumnya dilakukan oleh Herlina (2019) menyatakan terdapat pengaruh penggunaan pendekatan CTL (Contextual Teaching and Learning) terhadap hasil belajar IPA bila dibandingkan dengan kelompok peserta didik yang dibelajarkan dengan metode ekspository. Rahmawati (2018) menyatakan bahwa pengaruh positif pada penerapan model pembelajaran Contextual Teaching and Learning (CTL) terhadap motivasi peserta didik serta dapat meningkatkan hasil belajar peseta didik. Wiyono (2018) menyatakan kelompok siswa yang pembelajarannya dengan menggunakan metode pembelajaran CTL menunjukan hasil belajar IPA dan kemampuan berkomunikasi yang lebih tinggi dari pada kelompok siswa yang diajarkan dengan menggunakan metode pembelajaran langsung. Wati (2015) menyatakan terdapat pengaruh penerapan model Contextual Teaching and Learning terhadap motivasi belajar IPA. Hal tersebut dibuktikan dari hasil mean pada kelompok eksperimen lebih besar dari mean kelompok kontrol, Perbedaan dengan penelitian yang dilakukan pada penelitian yang relevan ini yaitu salah satunya kelas yang dijadikan penelitian dan tempat penelitian serta media yang digunakan dalam penelitian. Penelitian yang dilakukan kali ini yakni berbasis Tri Kaya Parisudha, yang diterapkan sampai akhir penelitian untuk menanamkan sikap moral, etika, disipilin, saling menghargai serta memotivasi siswa untuk mau belajar. Adapun tujuan dilaksanakannya penelitian ini untuk mengetahui pengaruh model Contextual Teaching and Learning Berbasis Tri Kaya Parisudha terhadap Kompetensi Pengetahuan IPA siswa kelas V SDN Gugus VIII Kecamatan Gianyar Tahun Ajaran $2019 / 2020$.

\section{METODE}

Penelitian ini termasuk penelitian eksperimen semu. Menggunakan design penelitian yaitu Non-Equivalent Control Group Design. Pola rancangan Non-equivalen Control Group Design. Tempat pelaksanaan penelitian ini di SDN Gugus VIII Tahun Ajaran 2019/2020. Kelompok eksperimen diberikan perlakuan yaitu dibelajarkan model Contextual Teaching and Learning Berbasis Tri Kaya Parisudha, sedangkan kelompok kontrol dibelajarkan secara konvensional. Populasi yang diambil dari keseluruh kelas V SDN Gugus VIII Tahun Ajaran 2019/2020 dengan jumlah 152 orang. Cara menentukan sampel menggunakan teknik random sampling dengan pengambilan acak. Langkah awal mengundi 6 kelas yang ada untuk mengambil dua yang dijadikan sebagai sampel, dengan cara menggulung 6 kertas yang berisikan kelas V SDN Gugus VIII kecamatan Gianyar, kemudian diundi untuk dijadikan sampel penelitian yaitu dua kelas yakni SDN 1 Siangan dan SDN 3 siangan. Sebelum diberikannya perlakuan pada kedua kelompok diberikan pretest terlebih dahulu untuk mengukur dan mengetahui ekuivalensi atau dapat disebut penyetaraan kelompo. Maka dari itu penelitian 
menggunakan pretest untuk menyetarakan kelompok dan untuk mengetahui keadaan pengetahuan awal siswa. Setelah dinyatakan setara diundi lagi dari dua kelas tersebut untuk dijadikan sebagai kelas eksperimen yang mendapat perlakuan model Contextual Teaching and Learning Berbasis Tri Kaya Parisudha, dan kelas kontrol yang tidak mendapat perlakuan atau pembelajaran konvensional. Dari hasil pengundian kelas V SDN 1 Siangan sebagai kelas eksperimen dengan perlakuan model Contextual Teaching and Learning Berbasis Tri Kaya Parisudha, sedangkan kelas kontrol diperoleh kelas V SDN 3 Siangan yang tidak mendapat perlakuan melainkan pembelajaran secara konvensional.

Data yang dikumpulkan dalam penelitian adalah Kompetensi Pengetahuan IPA kelas V. Metode yang digunakan untuk mengumpulkan data Kompetensi Pengetahuan IPA adalah tes pilihan ganda biasa dengan jumlah soal 40 butir dengan ketentuan apabila siswa menjawab benar nilainya 1 begitu juga sebaliknya apabila siswa menjawab salah nilainya 0 . Dengan demikian dari hasil nilai yang diperoleh siswa dalam menjawab soal dapat dijumlahkan sehingga memperoleh nilai Kompetensi Pengetahuan IPA. Sebelum digunakan, perangkat tes diuji untuk mengetahui kelayakan suatu tes secara keseluruhan maupun perbutir.

Analisis dalam penelitian ini melibatkan analisis inferensial. Analisi inferensial bertujuan untuk mengetahui sejauh mana kesamaan antara hasil yang didapat dari sampel dengan hasil populasi keseluruhan siswa kelas V. Uji inferensial meliputi uji prasyarat dan uji hipotesis. Adapun yang termasuk uji prasyarat adalah uji normalitas dan uji homogenitas. Uji homogenitas dalam penelitian ini menggunakan uji-t bertujuan untuk mengetahui adanya perbedaan pada kelompok eksperimen dan kelompok kontrol. Rumus uji-t yang digunakan adalah polled varians. Pemilihan rumus ini didasarkan pada ketentuan $\mathrm{n}_{1 \neq} \mathrm{n}_{2}$, data berditribusi normal dan varians homogen.

\section{HASIL DAN PEMBAHASAN}

Dari analisis data yang dilaksanakan hasil posttest Kompetensi Pengetahuan IPA, didapatkan hasil yang tersaji pada Tabel sebagai berikut:

Tabel 1. Deskripsi Data Kompetensi Pengetahuan IPA

\begin{tabular}{ccc}
\hline Statistik & Kelas Eksperiment & Kelas Kontrol \\
\hline Rerata & 83,97 & 76,91 \\
\hline Standar Deviasi & 8,74 & 7,30 \\
\hline Varians & 76,40 & 53,39 \\
\hline Skor Maksimum & 95 & 85 \\
\hline Skor Minimum & 65 & 60 \\
\hline
\end{tabular}

Bedasarkan tabel 1. Rerata nilai Kompetensi Pengetahuan IPA siswa kelas eksperimen tinggi daripada rerata kelas kontrol. Hasil posttest terhadap 38 kelas V SDN 1 Siangan yang melaksanakan model CTL Berbasis Tri Kaya Parisudha dalam kelas eksperimen bahwa nilai terbesar siswa adalah 95 dan nilai terkecil adalah 65 dengan rerata 83,97. Hasil tersebut berbeda dengan pemorolehan posttest kelas kontrol. Hasil posttest terhadap 36 kelas V SDN 3 Siangan yang melaksanakan pembelajaran secara konvensional dalam kelas kontrol, menunjukkan nilai terbesar yang didapat yaitu 85 dan skor terkecil ialah 60, dengan rerata 76,91. Sebelum melaksanakan uji hipotesis, dilakukan terlebih dahulu uji prasyarat, yaitu uji normalitas dan uji homogenitas. Dapat disajikan pada tabel 2 hasil analisis uji normalitas Kompetensi Pengetahuan IPA berikut ini.

Tabel 2. Hasil Uji Normalitas Kelompok Eksperimen dan Kelompok Kontrol

\begin{tabular}{ccccc}
\hline No & Sampel & $\mathbf{X}^{2}$ hitung & $\mathbf{X}^{2}$ tabel & Keterangan \\
\hline 1 & Kelas Eksperimen & 6,34 & 11,07 & Normal \\
\hline 2 & Kelas Kontrol & 5,06 & 11,07 & Normal \\
\hline
\end{tabular}

Berdasarkan tabel 2 dapat diuraikan hasil uji normalitas dapat disimpulkan data Kompetensi Pengetahuan IPA berdistribusi normal. analisis Chi-Square digunakan dalam uji normalitas dengan rumus $X^{2}$ hit $=\sum_{i}^{n} \frac{(f o-f e)^{2}}{f e}$. Dari hasil uji normalitas kelas eksperimen, nilai $X^{2}$ hitung yang diperoleh dari kelompok eksperimen $\mathrm{X}^{2}$ hit $=\sum_{i}^{n} \frac{(f \circ-f e)^{2}}{f e}=6,34$. Selanjutnya dibandingkan dengan $\mathrm{X}^{2}$ tabel dan $\mathrm{db}$ = 5 yang taraf signifikansi 5\% sehingga diperoleh nilai $\mathrm{X}^{2}$ tabel $=11,07$. Sebab $\mathrm{X}^{2}$ hitung $<\mathrm{X}^{2}$ tabel $(6,34<$ 
11,07) sehingga $\mathrm{H}_{0}$ diterima dan $\mathrm{H}_{\text {a }}$ ditolak. Ini berarti berdistribusi normal. Pada kelompok kontrol, hasil uji normalitas harga $X^{2}$ hitung yang diperoleh dari kelompok kontrol $X^{2}$ hit $=\sum_{i}^{n} \frac{(f \circ-f e)^{2}}{f \theta}=5,06$. Selanjutnya dibandingkan nilai $\mathrm{X}^{2}$ tabel dengan $\mathrm{db}=5$ yang taraf signifikansi $5 \%$ diperoleh nilai $\mathrm{X}^{2}$ tabel $=$ 11,07. Karena $\mathrm{X}^{2}$ hitung $<\mathrm{X}^{2}$ tabel $(5,06<11,07)$ sehingga $\mathrm{H}_{0}$ diterima dan $\mathrm{H}_{\text {a }}$ ditolak. Ini berarti berdistribusi normal.

Selanjutnya dilakukan uji homogenitas Kompetensi Pengetahuan IPA. kedua kelompok penelitian dilakukan uji homogenitas. Pengujian hipotesis varians menggunakan uji-F pada taraf signifikan 5\% dan $\mathrm{F}$ hitung = 1,43 . hasil uji homogenutas varians untuk taraf signifikansi $5 \% \mathrm{~F}$ tabel dengan $\mathrm{db}(37,35)$ adalah 1,72. Ini menunjukkan hasil $\mathrm{F}_{\text {hit }}<\mathrm{F}_{\text {tabel }}(1,43<1,72)$ sehingga data homogen. Dari hasil uraian tersebut, hasil uji prayarat yang terdiri dari uji normalitas dan uji homogenitas menunjukkan kedua data kelas eksperimen dan kelas kontrol berdistribusi normal serta homogen. Oleh karena itu apabila data sudah berditribusi normal dan homogen dapat dilanjutkan pada pengujian hipotesis. Hasil analisis uji-t data Kompetensi Pengetahuan IPA disajikan pada tabel 3 berikut.

Tabel 3. Hasil Uji-t Data Kompetensi Pengetahuan IPA

\begin{tabular}{|c|c|c|c|c|c|c|c|c|}
\hline No & Sampel & Rata-rata & Varians & Dk & $\mathbf{N}$ & $\mathbf{t}_{\text {hitung }}$ & $t_{\text {tabel }}$ & Simpulan \\
\hline \multirow[t]{2}{*}{1} & Kelas & 83,97 & 76,40 & \multirow{3}{*}{72} & 38 & \multirow{3}{*}{3,922} & \multirow{3}{*}{2,000} & \multirow{3}{*}{$\mathrm{H}_{\mathrm{a}}$ ditolak } \\
\hline & Eksperimen & & & & & & & \\
\hline 2 & $\begin{array}{l}\text { Kelas } \\
\text { Kontrol }\end{array}$ & 76,91 & 53,39 & & 36 & & & \\
\hline
\end{tabular}

Berdasarkan Tabel 3 tersebut, dijelaskan hasil dari pengujian hipotesis didapat $t_{\text {hitung }}=3,922$, dibandingkan dengan harga $t_{\text {tabel }}=2,000$, sebab $t_{\text {hitung }}>t_{\text {tabel }}=3,922>2,000$, jadi $H_{0}$ ditolak dan $H_{a}$ diterima. Sehingga terdapat perbedaan yang signifikan Kompetensi Pengetahuan IPA kelompok siswa yang dibelajarkan menggunakan model Contextual Teaching and Learning Berbasis Tri Kaya Parisudha dengan kelompok siswa yang dibelajarkan secara konvensional siswa kelas V SDN gugus VIII Kecamatan Gianyar Tahun Ajaran 2019/2020. Dari hasil penelitian ini memiliki perbedaan yang signifikan Kompetensi Pengetahuan IPA antara kelompok siswa yang dibelajarkan menggunakan model Contextual Teaching and Learning Berbasis Tri Kaya Parisudha, dengan kelompok siswa yang dibelajarkan secara konvensional. Oleh karena itu Kompetensi Pengetahuan IPA kelompok eksperimen lebih baik daripada kelompok kontrol, hal ini disebabkan karena pemberian perlakuan yang berbeda sehingga menyebabkan kecenderungan dalam skor yang diperoleh oleh siswa.

Dalam uji prasyarat analisis data diperoleh Kompetensi Pengetahuan IPA terhadap kelas eksperimen dan kelas kontrol ialah normal dan homogen. Diperolehnya uji prasyarat dan analisis data dilanjutkan dengan pengujian hipotesis, dengan taraf signifikansi $5 \%$ sehingga $\mathrm{H}_{0}$ di tolak dan $\mathrm{H}_{\mathrm{a}}$ di terima, jadi dirangkum terdapat perbedaan yang signifikan Kompetensi Pengetahuan IPA antara kelompok siswa yang dibelajarkan menggunakan model Contextual Teaching and Learning Berbasis Tri Kaya Parisudha, dengan kelompok siswa yang dibelajarkan secara konvensional pada siswa kelas $\mathrm{V}$ SDN di Gugus VIII Kecamatan Gianyar Tahun Ajaran 2019/2020.

Berdasarkan analisis data, 83,97 merupakan rerata kompetensi pengetahuan IPA kelompok eksperimen sementara itu 76,91 merupakan rerata kompetensi pengetahuan IPA kelompok kontrol. Jika kedua perolehan kompetensi pengetahuan IPA tersebut dibandingkan maka pemerolehan rerata kelompok eksperimen lebih maksimal dibandingkan dengan kelompok kontrol. Selanjutnya, melalui rumus pollend varians, 3,922 diperoleh sebagai $t_{\text {hit }}$ sementara 2,000 diperoleh sebagai $t_{\text {tabel }}$, $\mathrm{dk}=72$ dan taraf signifikansi $5 \%$. Jadi hasil analisis $t_{\text {hitung }}>t_{\text {tabel }}$ terjadinya penolakan $\mathrm{H}_{0}$ serta penerimaan $\mathrm{H}_{\mathrm{a}}$. Jadi disimpulkan bahwa model Contextual Teaching and Learning Berbasis Tri Kaya Parisudha berpengaruh terhadap Kompetensi Pengetahuan IPA siswa kelas V SDN Gugus VIII Kecamatan Gianyar Tahun Ajaran 2019/2020. Model Contextual Teaching and Learning dipadukan dengan kearifan lokal Tri Kaya Parisudha dapat memberikan pengalaman langsung serta membentuk karakter siswa agar siswa lebih disiplin saat proses pembelajaran sehingga dapat meningkatkan pembelajaran IPA. Hal itu karena model CTL dipadukan dengan kearifan lokal Tri Kaya Parisudha menekankan kepada siswa untuk mengkontruksi pengetahuannya sendiri yang berlandaskan sikap dan perilaku dalam pelaksanaan pembelajaran, contoh - contoh yang diberikan dalam pembelajaran dapat dialami langsung saat menerapkannya di kehidupan sehari-hari siswa. Hadiyanta (2011) menyatakan dengan menerapkan model Contextual Teaching and Learning, terjalinlah situasi belajar kerjasama, saling 
memotivasi, nyaman dan tidak membosankan, apabila siswa belajar dengan menggunakan gairah yang semangat proses pembelajaran dikelas akan aktif, sehingga siswa kritis saling sharing dengan teman maupun gurunya, maka pembelajaran berlangsung kondusif. Handini (2016) penerapan model CTL dapat dilakukan dengan mengaitkan pembelajaran terhadap kegiatan sehari-hari siswa yang dapat memudakan siswa dalam mengatasi setiap kesulitan dalam proses pembelajaran. Hal ini sejalan terhadap penelitian menurut Aryani (2013) model CTL dapat menumbuhkan hasil belajar yang berdampak langsung terhadap siswa yang semulanya siswa kurang aktif sehingga menjadi lebih aktif pada saat mengikuti kegiatana pembelajaran.

Menurut Dewi (2014) model NHT berlandaskan Tri kaya Parisudha dapat menambah hasil belajar IPA sehingga dalam meningkatkan tanggungjawab hasil belajar siswa serta dapat menumbuhkan semangat siswa. Menurut Agustiana (2013) model CTL berbantuan Media Gambar dapat meningkatkan aktivitas dan hasil belajar IPA siswa. Menurut Rahmawati (2018) model CTL dapat meningkatkan motivasi dan hasil belajar yang optimal. Wati (2015) menyatakan Model CTL terhadap Motivasi Belajar IPA mampu meningkatkan keatifan siswa dalam merespon dan menjawab soal. Hiqmawati (2013) menyatakan penggunaan model CTL dalam peningkatan pembelajaran IPA sangat efektif dilaksanakan terhadap proses pembelajaran IPA, oleh karena itu dilihat dari setelah pelaksanaan penelitian mengalami perubahan dalam peningkatan penilaian proses dan juga penilaian hasil. Hartini (2010) menyatakan dalam penggunaan model CTL peserta didik senang dan aktif pembelajaran IPA. Leni (2014) menyatakan menerapkan model CTL pada pembelajaran IPA sangat baik, karena dalam pelaksanaan pembelajaran guru menerapkan model CTL dengan memberikan bahan ajar berdasarkan konteks nyata siswa. Model CTL dipadukan dengan kearifan lokal Tri Kaya Parisudha memberikan pengalaman belajar bagi siswa dimana model CTL ini dapat mengaitkan materi yang diimpelementasikan dalam kegiatan sehari-hari yang dilandaskan dengan ajaran perilaku dan pola pikir yang baik, sehingga siswa dapat memperaktekkan langsung apa sudah diberikan oleh guru siswa dapat mengaplikasikannya pada saat kegiatan sehari-hari sehingga apa yang sudah dialami langsung oleh siswa akan selalu diingat dalam memori siswa bahwa siswa tersebut pernah mengalami apa yang sudah diberikan oleh guru.

Lain halnya dengan pembelajaran konvensional yang terjadi pada kelas kontrol pada proses pembelajaran IPA, kegiatan pembelajaran konvensional pada pembelajaran IPA kurang memberikan semangat dan juga gairah siswa dalam kelas sehingga pembelajaran menjadi kurang aktif dan efektif, hal ini disebabkan karena pembelajaran konvensional masih bepacu pada buku pegangan sehingga pembelajaran menjadi menoton. Pembelajaran kontektual dapat mengembangkan serta meningkatkan kreativitas dalam memecahkan masalah yang ada dilingkungan sekitar siswa, sebab dari siswa berpikir yang kreatif rasa keingintahuan siswa dan rasa bertanya siswa meningkat sehingga permasalahan dapat terselesaikan apabila mengembangkan permasalahan dengan apa yang dihadapi dikehidupan nyata (Ruiyanti, 2015). Model CTL membuat pembelajaran bermakna sebab mampu mengubah proses yang awalnya kondisi belajar siswa kurang aktif menjadi aktif serta mengubah yang awalnya berpusat pada guru menjadi berpusat pada siswa (Wiyono \& Budhi, 2018). Amertha (2011) dalam pendekatan Contextual Teaching and Learning (CTL) siswa dirangsang untuk aktif sehingga menimbulkan semangat belajar karena proses pembelajaran dikaitkan dengan kehidupan nyata, sehingga tujuan pembelajaran dapat tercapai dengan maksimal Sulimah (2016). Hasil penelitian ini menguatkan beberapa hasil penelitian yang ditemukan belakangan ini, yakni penelitian yang dilakukan oleh peneliti Widiantari (2019) dengan hasil terdapat terdapat perbedaan yang signifikan kompetensi pengetahuan IPA antara kelompok siswa yang dibelajarkan melalui model Contextual Teaching and Learning Berbasis Tri Hita Karana dengan kelompok siswa yang dibelajarkan melalui pembelajaran konvensional sehingga berpengaruh terhadap Kompetensi Pengetahuan IPA. Penelitian selanjutnya Wati (2015) dari hasil penelitian menunjukkan bahwa terdapat pengaruh penerapan model Contextual Teaching and Learning terhadap motivasi belajar IPA. Hal tersebut dibuktikan dari hasil mean pada kelompok eksperimen lebih besar dari mean kelompok control.

Untuk meningkatkan pencapaian tujuan pembelajaran berbasis Tri Kaya Parisudha di dalam pembelajaran siswa dapat berbuat baik dengan -temannya, beretika yang baik dan benar dan menumbuhkan rasa saling tolong menolong, rendah hati, tidak sombong, dan rasa simpati.Diterapkannya Tri Kaya Parisudha di dalam pelajaran IPA, siswa dapat meningkatkan motivasi belajarnya melalui kegiatan kerja sama atau belajar berkelompok serta berpikir, berkata dan berbuat sehingga siswa tidak mementingkan dirinya sendiri saat proses pembelajaran. Terbukti dengan menggunakan model pembelajaran Contextual Teaching and Learning berbasis Tri Kaya 
Parisudha yang diterapkan sampai akhir ekperimen, siswa dapat memahami konsep - konsep materi IPA melalui kegiatan berdiskusi dengan teman satu kelompoknya, saling tolong menolong saat hendak melakukan percobaan, dan bisa saling menghargai ketika ada teman yang memiliki pendapat yang berbeda. Siswa menjadi lebih aktif dikarenakan siswa dapat berpikir yang baik dan tidak mementingkan diri sendiri saat proses pembelajaran. Oleh karena itu siswa dapat memotivasi siswa yang lainnya untuk aktif dalam proses pembelajaran. Adapun penelitian lainnya Utami dkk (2019) meyatakan bahwa, model ini menerapkan konsep pengetahuan awal dengan melaui kegiatan berkelompok sehingga siswa lebih mudah memahami materi dan memecahkan permasalahan yang terdapat pada materi tersebut. Sependapat dengan Safitri (2019) pembelajaran yang dilandaskan kontruktivisme dapat menjadi dasar untuk menggali pengetahuan baru. Selain itu Nurhaliza (2019) berpendapat siswa dapat membangkitkan rasa percaya diri dan membangkitkan minat belajar siswa dikarenakan siswa mulai terbiasa dengan model Contextual Teaching and Learning.

Secara teoritis implikasi terhadap model pembelajaran ini membuktikan bahwa dalam proses pembelajaran khususnya pada materi IPA dapat meningkatkan kompetensi pengetahuan ipa siswa. Secara praktis implikasi terhadap model pembelajaran ini ditetapkan sebagai model pembelajaran alternatif. Dalam penelitian yang sebelumnya Arinda, dkk (2017) model pembelajaran ini melalui keterlibatan siswa, mampu meningkatkan kemampuan berpikir kompleks.

\section{SIMPULAN}

Dari hasil analisis data dan uji hipotesis terdapat perbedaan yang signifikan terhadap kompetensi pengetahuan IPA antara kelompok yang dibelajarkan menggunakan model pembelajaran Contextual Teaching and Learning Berbasis Tri Kaya Parisudha dengan kelompok yang tidak menggunakan model Contextual Teaching and Learning Berbasis Tri Kaya Parisudha pada kelas V Tahun Ajaran 2019/2020. Kelompok eksperimen memperoleh rerata kompetensi pengetahuan IPA lebih dari pada rerata kompetensi pengetahuan IPA di kelompok kontrol. Dapat disimpulkan bahwa model Contextual Teaching and Learning Berbasis Tri Kaya Parisudha berpengaruh secara signifikan terhadap kompetensi pengetahuan IPA kelas V Tahun Ajaran 2019/2020. Hasil analisis data guru disarankan agar menggunakan model Contextual Teaching and Learning Berbasis Tri Kaya Parisudha sebagai model pembelajaran alternatif dan dapat menambah wawasan guru tentang inovasi pembelajaran dalam meningkatkan kompetensi pengetahuan IPA siswa. Kepada kepala sekolah disarankan agar model ini dapat dipertimbangkan sebagai model pilihan dalam meningkatkan kompetensi pengetahuan IPA siswa. kepada peneliti lain disarankan dapat menggunakan hasil penelitian ini sebagai referensi penelitian untuk melaksanakan penelitian selanjutnya.

\section{DAFTAR PUSTAKA}

Arini, N. K. A. D., Murda, I. N., \& Agustiana, I. G. A. T. (2020). Korelasi Antara Rasa Ingin Tahu dan Motivasi Belajar dengan Hasil Belajar IPA Siswa Kelas V. Jurnal Mimbar Ilmu, 25(1), 20-31.

Afdoli. (2016). Pengaruh Model CTL Dengan Media Video Pembelajaran Terhadap Hasil Belajar IPA. https://lib.unnes.ac.id/24456/.

Amertha, Sri. (2015). Upaya Meningkatkan Aktivitas Dan Hasil Belajar IPA Dengan Menggunakan Pendekatan CTL. Vol 1. No 1. Jurnal PGSD FIP UNP. Universitas Negeri Padang.

Agustiana, Tri. (2013). Penerapan Model Pembelajaran CTL Berbantuan Media Gambar Untuk Meningkatkan Aktivitas dan Hasil Belajar IPA. Vol. 1 No. 1. https://ejournal.undiksha.ac.id/index.php/JJPGSD/article/view/915/0

Arisantiani, N. K., Putra, M., \& Ganing, N. N. (2017). Pengaruh Model Pembelajaran Childrens Learning In Science (Clis) Berbantuan Media Lingkungan Terhadap Kompetensi Pengetahuan Ipa. Journal Of Education Technology. Https://Doi.Org/10.23887/Jet.V1i2.11774

Aryani, Ni Kt. Sri (2013) . Penerapan Model Pembelajaran CTL (Contectual Teaching Learning) Berbantuan Media Gambar Untuk Meningkatkan Aktivitas Dan Hasil Belajar Ipa Siswa Kelas V. MIMBAR PGSD Undiksha. https://ejournal.undiksha.ac.id/index.php/JJPGSD/article/view/915/0

Ayu, I. G., W, I. W., Kt, D. B., \& Sem, N. (2020). Pengaruh Model Pembelajaran (SAVI) Berbasis (TIK) Terhadap Kompetensi Pengetahuan Matematika. 3(1), 15-24

Dantes, Nyoman.2012. Metode Penelitian. Yogyakarta : CV. Andi Offset. 
Jurnal Adat dan Budaya Vol. 2, No. 2, Tahun 2020, pp. 73-82

Dewi, Nym. Riska Yulistya (2013).Pengaruh Pendekatan CTL Berbantuan Penilaian Kinerja Terhadap Pemahaman Konsep Ipa Siswa Kelas $V$ Sd Negeri 1 Sangsit. Vol 1, No 1. https://ejournal.undiksha.ac.id/index.php/JJPGSD/article/view/732

Dewi, Synthia. 2019. Meningkatkan Kemampuan Berpikir Kreatif Ipa Siswa Sekolah Dasar Menggunakan Model Contexual Teaching And Learning. Journal of Elementary Education. Volume 02 Number 06, November 2019.

Hadiyanta, Nur. (2011). Penerapan Model Pembelajaran CTL Untuk Meningkatkan Hasil Belajar PKN. Vol 43. No. 1. Jurnal Kependidikan Penelitian Inovasi Pembelajaran. Universitas Negeri Yogyakarta.

Hamruni. (2011). Strategi Pembelajaran. Yogyakarta: Insan Madani

Handini, Dea. (2016). Penerapan Model Contextual Teaching and learning Meningkatkan Hasil Belajar Siswa. Vol. 1 No. 1. Jurnal Pena Ilmiah. Universitas Pendidikan Indonesia.

Hartini, Nanik. (2010). Penerapan model pembelajaran CTL untuk meningkatkan motivasi belajar IPA. Diss. Universitas Sebelas Maret.

Herawati, Endang Sri Budi. Pengaruh Model Pembelajaran Contextual Teaching And Learning (CTL) Menggunakan Media Kartu Terhadap Minat Belajar IPA Kelas IV. https://www.researchgate.net/publication/340682201_Pengaruh_Model_Pembelajaran_Con textual_Teaching_And_Learning_CTL_Menggunakan_Media_Kartu_Terhadap_Minat_Belajar_IP A_Kelas_IV_SD.

Herlina, L. (2019). Pengaruh Pendekatan Pembelajaran Contextual Teaching And Learning Dan Kreativitas Peserta Didik Terhadap Hasil Belajar Ipa Kelas V Di Sdn 147 Kota Jambi. Jurnal Pesona Dasar. https://doi.org/10.24815/pear.v7i2.14757

Hiqmawati, Yohana. (2013). Penggunaan model CTL Dalam Peningkatan Pembelajaran IPA.https://www.jurnal.fkip.uns.ac.id/index.php/pgsdkebumen/article/download/4247/29 89.

Kabanga, T., Tulak, T., \& Buli, S. (2019). Meningkatkan Hasil Belajar IPA Melalui Model Pembelajaran Learning Cycle 5E Pada Siswa Kelas IV SDN 101 Makale 4 Kecamatan Makale Kabupaten Tana Toraja. Elementary Journal, 1(2), 41-50.

Karwati, N. P. R., Wiyasa, K. N., \& Ardana, I. K. (2018). Pengaruh Model Pembelajaran Probing Prompting Berbantuan Multimedia Terhadap Hasil Belajar Ipa Siswa Kelas V Sd. Mimbar Ilmu, 23(2), 149-157. https://doi.org/10.23887/mi.v23i2.16421.

Laindjong. Sumanti. 2014. Meningkatkan Hasil Belajar Siswa Pada Pembelajaran Ipa Dengan Meenggunakan Media Gambar Di Kelas V Sdn 05 Biau. Vol 5. No 1

Maghfiroh, leni. (2014). Penerapan Model PembelajaranCTL Untuk Meningkatkan Hasil Belajar Siswa Pada Mata Pelajaran IPA. Jurnal Pendidikan Guru Sekolah Dasar. Universitas Negeri Surabaya.

Nurhaliza, Erisma. (2019). Penerapan Model CTL (Contextual Teaching And Learning) Melalui Alat Peraga Torso Dalam Peningkatan Hasil Belajar Pada Mata Pelajaran IPA Kelas V Di SDN Muara Bumban 1 Kabupaten Murung Raya. Vol 2, No 2. http://e-journal.iainpalangkaraya.ac.id/index.php/mdr/article/view/1837/0

Paramita.A, N. L. P. A., Japa, I. G. N., \& Sudatha, I. G. W. (2019). Pengaruh Model Contextual Teaching and Learning Berbantuan Masalah Realistis Terhadap Keterampilan Berpikir Kritis IPA. Thinking Skills and Creativity Journal. https://doi.org/10.23887/tscj.v1i2.20499

Putri, N. M. C. N. M., Ardana, I. K., \& Agustika, G. N. S. (2019). Pengaruh Model Discovery Learning Berbantuan Lingkungan Terhadap Kompetensi Pengetahuan Ipa Siswa Kelas V. Mimbar Pgsd.

Rahmawati, T. (2018). Penerapan Model Pembelajaran CTL Untuk Meningkatkan Hasil Belajar IPA. https://ejournal.undiksha.ac.id/index.php/JIPP/article/view/13765

Ruiyanti, R. (2015). Meningkatkan Hasil Belajar Siswa Pada Materi Pelajaran IPA Melalui Metode CTL. Jurnal Kreatif Tadulako Online.

Rusman. 2016. Model-model Pembelajaran.Jakarta:Rajawali pers.

Sanjaya, W. (2010). Strategi Pembelajaran Berorientasi Standar Proses Pendidikan. In System.

Setyowati, Nuning \& Wulandari, Desi. (2017). Keefektifan Pendekatan Ctl Terhadap Hasil Belajar Ipa Materi Sumber Daya Alam.

Https://www.researchgate.net/publication/319248558_KEEFEKTIFAN_PENDEKATAN_CTL_ TERHADAP_HASIL_BELAJAR_IPA_MATERI_SUMBER_DAYA_ALAM. 
Shoimin, Aris. 2014. 68 Model Pemeblajaran Inovatif dalam Kurikulum 2013. Yogyakarta:Ar-Ruzz Media.

Suanthara, I. N. D. E. (2018). Pengaruh Model Pembelajaran Tri Kaya Parisudha Terhadap Prestasi Belajar Mahasiswa Semester V Prodi Pendidikan Agama Hindu Stkip Agama Hindu Singaraja Tahun Akademik 2016/2017. Jurnal PASUPATI. https://doi.org/10.37428/pspt.v5i2.31.

Sudjana, N. (2013). Dasar-dasar proses belajar. Jurnal Pendidikan.

Suhardana, K.M. 2007. Tri Kaya Parisudha. Bahan Kajian Untuk Berpikir Baik, Berkata Baik, dan Berbuat Baik. Surabaya: Paramitha

Sulimah. 2016. Implementasi Pendekatan Contextual Teaching And Learning (Ctl) Dalam Pembelajaran Ipa Di Madrasah Ibtidaiyah Negeri Purwokerto. Skripsi.

Trianto (2009). Mendesain Model Pembelajaran Inovatif Progresif. Surabaya:Kencana

Triyana, A., Rara, Y., Agung, I. G., \& Negara, O. (2020). Pengaruh Model Pembelajaran ( SAVI ) Berbantuan Multimedia Terhadap Kompetensi Pengetahuan IPA. 8, 40-49.

Warsiki, N. M. (2018). Penerapan Metode Pembelajaran Discovery Meningkatkan Prestasi Belajar Ipa. $\begin{array}{llll}\text { Jurnal Imiah Pendidikan Dan Pembelajaran, } 287 . & \end{array}$ https://doi.org/10.23887/jipp.v2i3.16226

Wati, N. M. (2015). Pengaruh Model CTL Terhadap Motivasi Belajar IPA. https://eprints.uny.ac.id/22584/1/NILA\%20MERDEKA\%20WATI_11108241087.

Widiasworo, 2018. Penelitian Pendidikan Modern. Yogyakarta: Pustaka Pelajar.

Widianingrum, W. M., Mulyani, S., \& Utomo, S. B. (2018). Pengaruh Model Pembelajaran Problem Solving Dan Learning Cycle 5E Terhadap Prestasi Belajar Ditinjau Dari Kemampuan Metakognisi Siswa Pada Materi Larutan Penyangga. Pedagogia, 21(2), 186.

Widiantari, 2019. Pengaruh Model CTL Berbasis Tri Hita Karana Terhadap Kompetensi Pengetahuan IPA. https://ejournal.undiksha.ac.id/index.php/JJPGSD/article/view/839.

Widiantini, N. N. A. S., Putra, M., \& Wiarta, I. W. (2017). Model Pembelajaran Sets (Science, Environment, Technology, Society) Berbantuan Virtual Lab Berpengaruh Terhadap Kompetensi Pengetahuan Ipa. Journal of Education Technology. Https://Doi.Org/10.23887/Jet.V1i2.11776

Wiyono, B. H., \& Budhi, W. (2018). Pengaruh Metode Pembelajaran Ctl Terhadap Hasil Belajar Ipa Siswa Kelas Viii Ditinjau Dari Kemampuan Berkomunikasi. Natural: Jurnal Ilmiah Pendidikan IPA. https://doi.org/10.30738/natural.v5i1.2561

Yuliana, N. (2018). Penggunaan Model Pembelajaran Discovery Learning Dalam Peningkatan Hasil Belajaran Siswa Di Sekolah Dasar. Pedagogi: Jurnal Ilmu Pendidikan, 18(2), 56.

Yunita., \& Wijayanti, R. (2019). Pengaruh Penggunaan Model Pembelajaran Learning Cycle 5E Terhadap Hasil Belajar Siswa dalam Memecahkan Masalah Matematis Berbentuk Soal Cerita. Keguru: Jurnal Ilmu Pendidikan Dasar, 6(3), 22-28. 